\title{
PENDAMPINGAN KELOMPOK USAHA PENCACAHAN LIMBAH PLASTIK DI KABUPATEN MALANG
}

\author{
Adi Wijayanto ${ }^{1)}$ dan Rusdi $^{2)}$ \\ FTIK - IAIN Tulungagung, Jl. Mayor Sujadi Timur, 46 Tulungagung \\ 1) email: wijayantoadi@yahoo.com \\ 2) email:rusdi_20@rocketmail.com
}

\begin{abstract}
Plastic bottles have become part of the daily activities, especially in activities relating to packaging of mineral water. The use of plastic bottles for packaging of mineral water is an alternative that is practical and concise, but on the other hand is also harmful to the environment because it adds to discharge garbage plastic bottles. Plastic bottles is not derived from biological compounds, plastic bottles have difficult nature degraded (non - biodegradable) that can contaminate soil, water, sea, and even air. Specific target science and technology community service programs for the community (IBM) are (1) understanding of the technological waste processing machine plastic bottles into plastic pellets, (2) the public's understanding of the plastic bottle waste management, (3) labor absorption and production of plastic pellets more leverage. The program will increase the sale value of plastic garbage that has become plastic pellets, so as to improve the economic welfare of society. Activities in this program include: (1) design and design thrasher plastic pellets, (2) sending power to the transfer of knowledge (apprentice), (3) socialization to the community group enumerator plastic pellets, (4) submission thrasher plastic pellets, (5) trial thrasher plastic pellets, (6) the application of machines in the field and practice of making plastic pellets, (7) management training.
\end{abstract}

Keywords: machine, plastic pellets, trash

\section{PENDAHULUAN}

Sejak tahun 1950-an plastik menjadi bagian penting dalam hidup manusia. Plastik digunakan sebagai bahan baku kemasan, tekstil, bagian-bagian mobil dan alat-alat elektronik. Dalam dunia kedokteran, plastik bahkan digunakan untuk mengganti bagian-bagian tubuh manusia yang sudah tidak berfungsi lagi. Pada tahun 1976 plastik dikatakan sebagai materi yang paling banyak digunakan dan dipilih sebagai salah satu dari 100 berita kejadian pada abad ini (Angelfire, 2012:1). Menurut perhitungan Kementrian Lingkungan Hidup, jumlah sampah botol plastik penduduk Indonesia setiap harinya sebesar 23.600 ton dan saat ini sampah botol plastik telah menumpuk hingga 6 juta ton, atau setara dengan berat 1 juta gajah dewasa (tempointeraktif, 2012:1).
Sedangkan menurut Abraha Gebrekidan Asgedom dan Mulu Berhedesta (2012: 81) bahwa penanganan yang buruk, menggunakan kembali dan pembuangan sampah botol plastik merupakan penyebab utama pencemaran lingkungan, menjadi karsinogenik untuk manusia, dan organisme.

Botol plastik seperti yang sudah kita ketahui merupakan jenis sampah atau limbah yang proses penguraiannya membutuhkan waktu yang lama yaitu sekitar 5-1000 tahun. Bisa dibayangkan berapa waktu yang dibutuhkan untuk mengurai sampah botol plastik yang kita hasilkan dalam 1 hari. Selain susah untuk diurai alam, botol plastik juga merupakan produk yang tidak ramah lingkungan karena untuk memproduksi satu ton kantong plastik membutuhkan 1.800 liter minyak mentah, dan setiap 1 botol plastik menghasilkan polusi udara sebesar 544 gram (Lilis Sulistyorini: 2005: 78). 
Botol plastik sudah menjadi bagian dalam kegiatan sehari-hari terutama dalam kegiatan yang berkaitan dengan pembungkus air mineral. Penggunaan botol plastik sebagai pembungkus air mineral memang alternatif yang praktis dan ringkas, tetapi di sisi lain juga membahayakan lingkungan karena menambah debit sampah botol plastik yang terbuang (Tozy Sentosa, 2012:1). Dampak botol plastik terhadap lingkungan merupakan akibat negatif yang harus ditanggung alam karena keberadaan sampah botol plastik. Dampak ini ternyata sangat signifikan. Sebagaimana yang diketahui, botol plastik yang mulai digunakan sekitar 50 tahun yang silam, kini telah menjadi barang yang tidak terpisahkan dalam kehidupan manusia. Diperkirakan ada 500 juta sampai 1 milyar botol plastik digunakan penduduk dunia dalam satu tahun. Ini berarti ada sekitar 1 juta botol plastik per menit. Untuk membuatnya, diperlukan 12 juta barel minyak per tahun, dan 14 juta pohon ditebang.

Konsumsi berlebih terhadap pemakaian botol plastik mengakibatkan jumlah sampah botol plastik semakin membesar. Karena bukan berasal dari senyawa biologis, botol plastik memiliki sifat sulit terdegradasi (nonbiodegradable). Botol plastik diperkirakan membutuhkan waktu 100 hingga 500 tahun hingga dapat terdekomposisi (terurai) dengan sempurna. Sampah botol plastik dapat mencemari tanah, air, laut, bahkan udara.

Untuk menanggulangi sampah botol plastik beberapa pihak mencoba untuk membakarnya. Tetapi proses pembakaran yang kurang sempurna dan tidak mengurai partikel-partikel plastik dengan sempurna maka akan menjadi dioksin di udara. Bila manusia menghirup dioksin ini manusia akan rentan terhadap berbagai penyakit di antaranya kanker, gangguan sistem syaraf, hepatitis, pembengkakan hati, dan gejala depresi. Kita memang tidak mungkin bisa menghapuskan penggunaan botol plastik $100 \%$, tetapi yang paling memungkinkan adalah dengan memakai ulang plastik (reuse), mengurangi pemakaian plastik (reduce), dan mendaur ulang (recycle). Terakhir, mungkin perlu regulasi dari pemerintah untuk meredam semakin meningkatnya penggunaan plastik (alamedah, 2009:1).

Daur ulang adalah proses untuk menjadikan suatu bahan bekas menjadi bahan baru dengan tujuan mencegah adanya sampah yang sebenarnya dapat menjadi sesuatu yang berguna, mengurangi penggunaan bahan baku yang baru, mengurangi penggunaan energi, mengurangi polusi, kerusakan lahan, dan emisi gas rumah kaca jika dibandingkan dengan proses pembuatan barang baru. Daur ulang adalah salah satu strategi pengelolaan sampah padat yang terdiri atas kegiatan pemilahan, pengumpulan, pemrosesan, pendistribusian dan pembuatan produk / material bekas pakai, dan komponen utama dalam manajemen sampah modern dan bagian ketiga adalam proses hierarki sampah 3R (Reuse, Reduce, and Recycle).

Sampah botol plastik selama ini benar-benar hanya dilihat sebagai sampah semata. Hampir-hampir tidak ada yang bisa melihat sisi positif pada sampah botol plastik, bahkan pemulung pun enggan mengumpulkannya. Padahal sejatinya, sampah botol plastik ini bisa didaur ulang menjadi bahan baku pembuatan plastik. Permintaan terhadap bahan baku ini pun sangat besar sehingga pabrik pembuatan plastik sering kehabisan stok bahan baku. Belum lagi kalau dilihat dari sisi penyerapan tenaga kerjanya. Dalam usaha ini banyak pihak yang bisa terlibat di dalamnya. Misalnya pemulung, penampung, bandar sampah botol plastik bekas, maupun pemasok ke perusahaan daur ulang sampah botol plastik.

Di dalam perusahaan/pabrik daur ulang sampah botol plastik sendiri 
banyak menampung tenaga kerja dari mulai: tenaga sortir plastik, tenaga giling, tukang pres, tukang jemur, tenaga pengepakan/packing sampai staf administrasi dan keuangan, mereka semua mendapatkan upah yang cukup lumayan dan memadai untuk menunjang kebutuhan hidup sehari-hari. Usaha daur ulang botol plastik, juga sangat berperan dalam membantu dan memelihara kebersihan lingkungan. (Boy Macklin, 2008:1).

Pemerintah Kabupaten Malang, Pemkab Malang kesulitan mengelola sampah non organik sejenis sampah botol plastik. Penyebabnya, ketiadaan teknologi pengelolaan di seluruh tempat pembuangan akhir (TPA) di Kabupaten Malang. Padahal, sampah botol plastik bisa bernilai tinggi jika diolah menjadi biji plastik yang secara ekonomi menguntungkan masyarakat. "Karena tidak bisa diolah, sampah botol plastik langsung dikirim ke industri pengolahan biji plastik. Padahal kalau bisa diolah sendiri lebih bagus, karena nilai ekonominya bisa lebih tinggi," kata Romdhoni, Kepala Dinas Cipta Karya dan Tata Ruang Kabupaten Malang,

Menurutnya, para petugas pemilah sampah di TPA menyetor sampah botol plastik ke industri pengolahan biji plastik. Di pihak swasta, sampah botol plastik hanya dihargai $\mathrm{Rp} 400$ per $\mathrm{Kg}$, sementara untuk kantong plastik dihargai Rp 800 per Kg. Padahal, bila sudah diolah dan menjadi biji plastik, harga jualnya bisa melambung menjadi $\mathrm{Rp}$. $8.000 \mathrm{~kg}$. Pengolahan sampah menjadi biji plastik sendiri sebenarnya bisa menguntungkan para petugas pemilah sampah dan masyarakat sekitar TPA."Kami dulu sudah pernah berencana membeli alat pengolahan dengan menyiapkan anggaran $\mathrm{Rp} 18$ juta, tapi ternyata harganya Rp 35 juta. Karena itu, kami mengurungkan pengadaan alat pengolah tersebut," tandas Romdoni.

Volume sampah di Kabupetan Malang sebanyak 3 ribu meter kubik per hari. Komposisinya, 60\% sampah organik dan $40 \%$ sampah non organik. Untuk sampah organik, diolah secara komposting dan dimanfaatkan untuk pupuk bagi pertanian. Kalau hasil komposting sampah organik, pemasarannya sudah jelas. Tapi kalau sampah botol plastik ini yang sebenarnya potensial tapi belum dimaksimalkan pengelolaannya.

IbM kelompok usaha pencacahan limbah sampah botol plastik air mineral ini semula direncanakan di desa Kebonangung dan desa Mangliawan Kabupaten Malang. Namun dalam perkembangannya karena berbagai hal kemudian pelaksanaannya di pindahkan ke desa Girimoyo Kecamatan Karangploso Kabupaten Malang.Bapak Suyadi, merupakan salah satu warga RT.34/ RW.06 No. 37 Kebonagung Kecamatan Pakisaji Kabupaten Malang yang menekuni usaha pencacahan limbah plastik. Ketika disurvei untuk calon Mitra IbM (1), ia menuturkan bahwa usaha pencacahan sampah botol plastiknya sudah dimulai sejak tahun 2004 dan usahanya mempunyai prospek untuk dikembangkan karena permintaan akan biji plastik terus mengalami peningkatan setiap tahunnya. Pengelolaan usaha limbah plastik Bapak Suyadi ini dikelola dengan manajemen seadanya, sehingga hasilnya baik dari segi produksi maupun pemasaran tidak dapat dimaksimalkan. Selain itu para mitra usahanya seperti para pengumpul sampah botol plastik yang menjadi langganannya sering meminjam uang dan sering pula tidak mengembalikan bahkan mereka berpindah ke tempat usaha pengolahan limbah plastik yang lain. Untuk Bapak Suyadi sebagai Mitra (1) bantuan yang diberikan adalah pelatihan manajemen dan penempatan magang mitra (2) IbM.

Bapak Fery di Desa Girimoyo Kecamatan Karangploso Kabupaten Malang sebagai Mitra IbM (2) adalah sebagai Ketua Kelompok Bank Sampah 
di RT. 18 RW. 04 RW.18. Desa Girimoyo. Ketika disurvei sebagai calon Mitra IbM (2), beliau menyampaikan keinginanya untuk mengelola usaha pengolahan sampah botol plastik menjadi biji palstik. Akan tetapi semuanya itu terkendala oleh pengetahuan cara pengolahan limbah plastik menjadi biji palstik, teknologi/mesin, manajemen serta pembiayaan yang cukup besar untuk mendirikan usaha pencacahan limbah plastik tersebut. Akan tetapi Bapak Fery ini mempunyai lahan yang cukup representatif untuk usaha pencacahan limbah sampak plastik ini. Oleh karena itu tim IbM memutuskan memindahkan tempat pelaksanaan IbM ini ke Desa Girimoyo Kecamatan Karangploso. Disamping itu Bapak Tony Artaka sebagai calon mitra (2) ternyata setelah disurvei ulang tidak siap untuk melaksanakan program IbM pencacahan limbah sampai plastik dikarenakan tidak adanya lahan yang cukup tersedia dan kesibukan dengan pekerjaannya. Oleh karena itu tim IbM mengalihkan tempat pelaksanaan IbM ke Desa Karangploso Kecamatan Karangploso Kabupaten Malang yang dikelola oleh Bapak Fery.

Setelah kegiatan program IbM ini selesai, target luaran yang ingin dicapai dapat dirangkum dalam tabel berikut ini.

Tabel 1. Luaran

\begin{tabular}{|c|l|l|l|}
\hline No. & \multicolumn{1}{|c|}{ Masalah mitra } & \multicolumn{1}{|c|}{ Solusi } & \multicolumn{1}{c|}{ Output } \\
\hline 1 & $\begin{array}{l}\text { Kurangnya pengetahuan } \\
\text { masyarakat tentang } \\
\text { pengolahan limbah sampah } \\
\text { botol plastik }\end{array}$ & $\begin{array}{l}\text { Diberikan penyuluhan dan } \\
\text { pelatihan tentang } \\
\text { teknologi pengolahan } \\
\text { limbah sampah botol } \\
\text { plastik }\end{array}$ & $\begin{array}{l}\text { Pemahaman masyarakat } \\
\text { tentang pengelolaan sampah } \\
\text { botol plastik meningkat }\end{array}$ \\
\hline 2 & $\begin{array}{l}\text { Belum ada kelompok } \\
\text { masyarakat di desa IbM (2) } \\
\text { mesin pengolah sampah botol } \\
\text { plastik }\end{array}$ & $\begin{array}{l}\text { Memberikan teknologi/ } \\
\text { mesin pengolah sampah } \\
\text { botol plastik }\end{array}$ & $\begin{array}{l}\text { Terbentuknya kelompok- } \\
\text { kelompok wirausahaan baru } \\
\text { di bidang pengolahan } \\
\text { sampah botol plastik }\end{array}$ \\
\hline 3 & $\begin{array}{l}\text { Rendahnya penguasaan } \\
\text { teknologi mesin pengolah } \\
\text { sampah botol plastik }\end{array}$ & $\begin{array}{l}\text { Memberikan penyuluhan } \\
\text { dan pelatihan tentang } \\
\text { pemanfaatan teknologi } \\
\text { mesin pengolah sampah } \\
\text { botol plastik }\end{array}$ & $\begin{array}{l}\text { Pemahaman masyarakat akan } \\
\text { teknologi mesin pengolah } \\
\text { sampah botol plastik menjadi } \\
\text { biji plastik. }\end{array}$ \\
\hline 4 & $\begin{array}{l}\text { Desa lokasi IbM (1) perlunya } \\
\text { manajemen pengolahan } \\
\text { sampah botol plastik }\end{array}$ & $\begin{array}{l}\text { Pemberian manajemen } \\
\text { pengolahan sampah } \\
\text { palstik }\end{array}$ & $\begin{array}{l}\text { Penyerapan tenaga kerja dan } \\
\text { produksi biji plastik lebih } \\
\text { maksimal. }\end{array}$ \\
\hline
\end{tabular}

Nilai Tambah Produk Dari Sisi IPTEKS bagi mesin pencacahan limbah sampah botol plastik air mineral yaitu dapat memberikan dampak positif terhadap kelompok kelompok usaha pencacahan limbah sampah botol plastik menjadi barang produksi yang bernilai ekonomi dalam bentuk palet atau biji plastik dengan nilai jual yang lebih tinggi dibandingkan berupa botol plastik saja.

Alat ini memiliki kemampuan yang prima karena mesin pencacahan limbah sampah botol plastik air mineral ini mempunyai 6 pisau putar dan 2 pisau tetap dengan bahan pisau terbuat dari baja karbon dengan kekerasan pisau $500 \mathrm{HV}$, sehingga botol plastik padi akan lebih cepat dicacah. Kapasitas kerja mesin pencacahan limbah sampah botol plastik air mineral: 20-50 kg/jam dengan kuran biji plastik yang dihasilkan: $1-2 \mathrm{~cm}^{2}$. Mesin pencacahan limbah sampah botol plastik air mineral memiliki berat kurang lebih $100 \mathrm{~kg}$ dan berat diesel kurang lebih $70 \mathrm{Kg}$, sehingga berat Keseluruhan kurang lebih $170 \mathrm{~kg}$. 


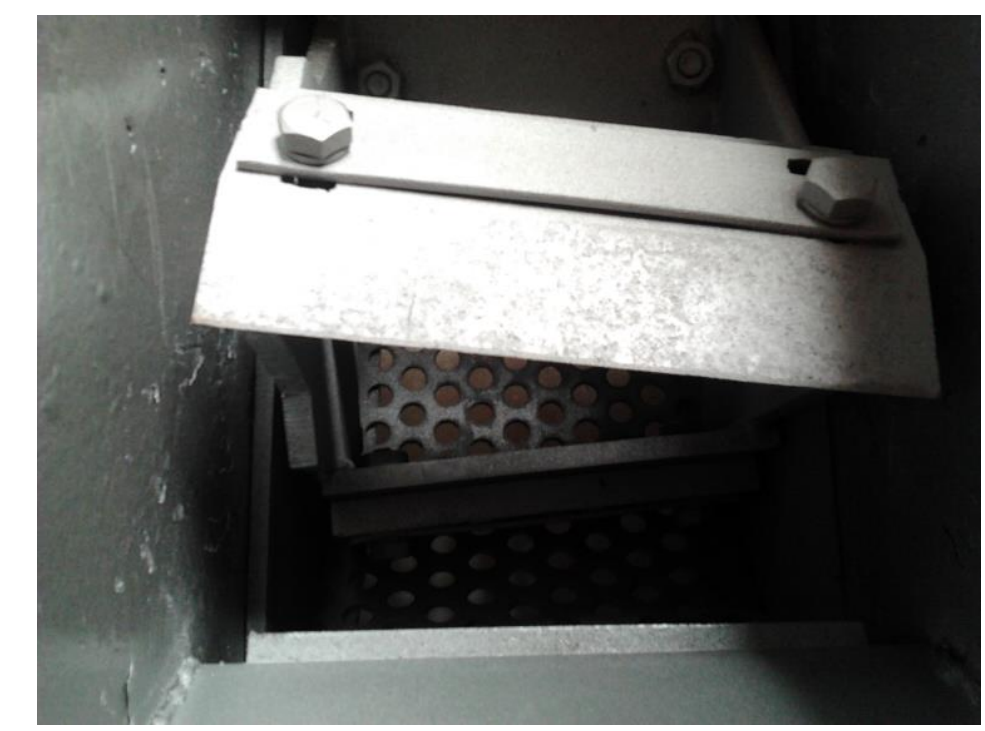

Gambar 1. Pisau Putar mesin pencacah sampah botol plastik

Alat ini dikendalikan secara mudah, praktis, bekerja secara non-stop serta secara mekani mudah dalam perawatan dan perbaikan. Alat ini dapat memberikan tambahan wawasan dan pengalaman inovasi teknologi bagi kelompok usaha pencacahan limbah sampah botol plastik.

\section{METODE}

Ketika disurvei untuk calon Mitra IbM 1, beliau menuturkan bahwa usaha pencacahan sampah botol plastiknya sudah dimulai sejak tahun 2004 dan usahanya mempunyai prospek untuk dikembangkan karena permintaan akan biji plastik terus mengalami peningkatan setiap tahunnya. Pengelolaan usaha limbah plastik Bapak Suyadi ini dikelola dengan manajemen seadanya, sehingga hasilnya baik dari segi produksi maupun pemasaran tidak dapat dimaksimalkan. Selain itu para mitra usahanya seperti para pengumpul sampah botol plastik yang menjadi langganannya sering meminjam uang dan sering pula tidak mengembalikan bahkan mereka berpindah ke tempat usaha pengolahan limbah plastik yang lain.

Ketika disurvei sebagai calon Mitra IbM 2, beliau menyampaikan keinginanya untuk mengelola usaha pengolahan sampah botol plastik menjadi biji palstik.
Akan tetapi semuanya itu terkendala oleh pengetahuan cara pengolahan limbah plastik menjadi biji palstik, teknologi/mesin, manajemen serta pembiayaan yang cukup besar untuk mendirikan usaha pencacahan limbah plastik tersebut. Akan tetapi Bapak Fery ini mempunyai lahan yang cukup representatif untuk usaha pencacahan limbah sampak plastik ini.

Dengan adanya permasalahan mitra di atas maka, solusi yang ditawarkan adalah: (1) Untuk Mitra I bantuan yang diberikan adalah pelatihan manajemen dan penempatan magang mitra, pemberian manajemen pengolahan sampah plastik, (2) Untuk Mitra II bantuan yang diberikan adalah Memberikan teknologi/ mesin pengolah sampah botol plastik, Memberikan penyuluhan dan pelatihan tentang pemanfaatan teknologi mesin pengolah sampah botol plastik, serta penyuluhan dan pelatihan tentang teknologi pengolahan limbah sampah botol plastik

Kegiatan dalam program ini meliputi: (1) perancangan dan mendesain mesin pencacah biji plastik, dengan hal ini desain prototipe oleh tim peneliti, sedangkan pelaksanaan dilapangan dalam pengerjaann mesinnya oleh teknisi (2) pengiriman tenaga untuk transfer ilmu (magang), (3) sosialisasi kepada 
masyarakat kelompok pencacah biji plastik, (4) penyerahan mesin pencacah biji plastik, (5) uji coba mesin pencacah biji plastik, (6) penerapan mesin di lapangan dan praktek pembuatan biji plastik, (7) pelatihan manajemen.

Jadwal kegiatan pelaksanaan Iptek Bagi Masyarakat (IBM) dirinci seperti berikut: (1) Persiapan program, observasi untuk pendataan calon Mitra IbM, (2) Pengembangan Desain Prototipe mesin pencacah biji plastik, (3) Pembuatan mesin pencacah biji plastik, (4) Koordinasi dengan tempat magang Dan pelaksanaan magang, (5) Pemantauan progres kerja di teknisi dan umpan balik keefektifan kerja prototipe mesin pencacah biji plastik, (6) Kunjungan ke tempat Mitra Program IbM II untuk membahas pengiriman dan penempatan mesin pencacah biji plastik, (7) Uji coba kekuatan diesel penggerak dan analisis, (8) Penyerahan, pengiriman dan penempatan mesin pencacah biji plastik di Mitra Program IbM II, (9) Sosialisasi kepada masyarakat di Mitra Program IbM II

\section{HASIL DAN PEMBAHASAN}

Kegiatan awal program ini adalah mendesain dan merancang mesin pencacah biji plastik, produk akhir dari program ini adalah prototipe dalam bentuk gambar ilustrasi dan cara kerja mesin pencacah biji plastik. Dalam perancangannya mengalami beberapa permasalahan, diantaranya adalah presisi dari 6 pisau gerak dan 2 pisau tetap yang banyak menimbulkan gesekan, sehingga jika dilakukan dalam jangka yang panjang dapat mengakibatkan kerusakan pada mesin. Namun teknisi mencoba dengan memindahkan poros putaran pada mesin putar, sehingga mesin bisa sempurna.

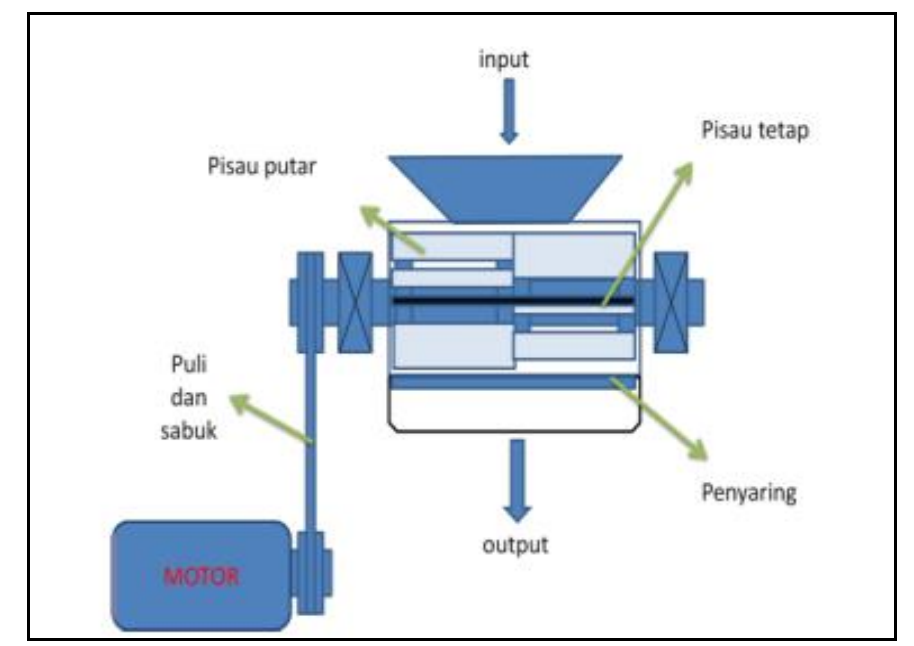

Gambar 2. Prototipe mesin pencacah sampah botol plastik

Kegiatan yang kedua adalah pengiriman tenaga untuk transfer ilmu (magang), dalam kegiatan magang tersebut dihasilkan beberapa tenaga yang diharapkan dapat mengoperasionalkan mesin pencacah biji plastik, serta mengerti tentang jenis-jenis plastik yang dapat diolah.

Kegiatan yang ketiga adalah sosialisasi kepada masyarakat kelompok pencacah biji plastik, pada penyuluhan dan pelatihan serta sosialisasi tentang teknologi pengolahan limbah sampah botol plastik pada mitra program IbM II yang berlokasi di desa Girimoyo Kecamatan karangploso dihasilkan beberapa kemajuan diantaranya adalah: (1) mitra IbM II (bapak fery) bisa mengoperasikan mesin pencacah biji plastik dengan dibantu beberapa masyarakat sekitar karena ada transfer ilmu dari teknisi ke masyarakat, (2) warga antusias dalam pelatihan pengolahan biji plastik dan sepakat diadakannya bank 
sampah, dimana masyarakat sekitar mitra IbM II dapat menyetorkan sampah botol plastik yang sudah dalam keadaan bersih untuk ditabung pada mitra IbM II, dan pengambilan uangnya dilakukan 3 hingga 6 bulan, (3) ada 3 warga sekitar mitra IbM II yang siap menjadi tenaga kerja pada mitra IbM II, sehingga berdampak pada pengurangan pengangguran.

Lingkungan tempat kegiatan pengabdian masyarakat sangat kondusif dan memadahi, dimana pusat pengabdian akan berlangsung di IKIP Budi Utomo Malang dan tempat mitra (desa kebon agung Kec.Pakisaji dan desa Girimoyo Kec.Karangploso). Lingkungan di IKIP Budi Utomo Malang mempunyai beberapa fasilitas penunjang yang dapat dimanfaatkan selama kegiatan penelitian berlangsung, diantaranya adalah: (1). Fasilitas koneksi wireless yang dapat digunakan untuk mengakses jaringan internet, sehingga informasi tentang teori teknik permesinan dapat dengan mudah diakses. (2) Laboratorium untuk mendesain prototipe mesin pencacah biji plastik.

Pada sosialisasi banyak pertanyaan mengenai pencemaran air, udara, suara, namun oleh peneliti menjelaskan bahwa dampak pencemaran air akibat pencacahan biji plastik bisa dikatakan tidak ada/ tidak mencemari air, sebab plastik yang mau dicacah oleh pemulung harus sudah dibersihkan, sehingga kelompok usaha pencacah plastik tinggal menggiling saja, mengenai pencemaran udara yang dihasilkan dari porses tesebut sangat kecil, sebab asap solar pada mesin diesel hanya sedikit dan dibuatkan cerobong asap dengan pemberian filter, namun pencemaran suara merupakan permasalahan yang serius, akan tetapi peneliti memberikan solusi pembuatan peredam suara dengan cara memberikan double tembok yang ditengahnya diberikan peredam dari busa/ stereofoam, namun solusi itu belum terlaksana dikarenakan keterbatasan dana.

Kegiatan yang keempat adalah penyerahan mesin pencacah biji plastik, dalam hal ini diwakili oleh mitra IbM II dengan disaksikan oleh warga sekitar dan kepala desa Girimoyo. Dalam penyerahan tersebut kepala desa menganjurkan untuk tidak hanya sampai pada program pencacahan biji plastik, melainkan di waktu yang akan datang ada programprogram yang lain yang dapat meningkatkan taraf hidup dan ekonomi warga desa Girimoyo.

Kegiatan yang kelima adalah uji coba mesin pencacah biji plastik dan uji coba kekuatan diesel penggerak, dimana akan dihitung jumlah hasil cacahan biji plastik, serta analisis terhadap daya cacah mesin. Dalam tahapan proses daur ulang plastik, banyak melibatkan tenaga yang dikoordinir oleh mitra IbM mulai dari pemilahan warna pet/botol plastik, pembersihan dari kotoran dan tutup botol, sampai proses penggilingan plastik.

Kegiatan dilanjutkan yang keenam yaitu penerapan mesin di lapangan dan praktek pembuatan biji plastik di mitra IbM II, pada kegiatan tersebut pada awalnya warga sekitar belem mengetahui bahwa untuk mendapatkan biji yang baik tidak bisa hanya satu kali pencacahan, namun butuh lebih dari satu (antara 2-4) kali pencacahan dari botol plastik yang dicacah berulang-ulang. Namun dari 4 kali pencacahan tersebut, biji plasti sudah mencapai ukuran $2 \mathrm{~cm}^{2}$. 


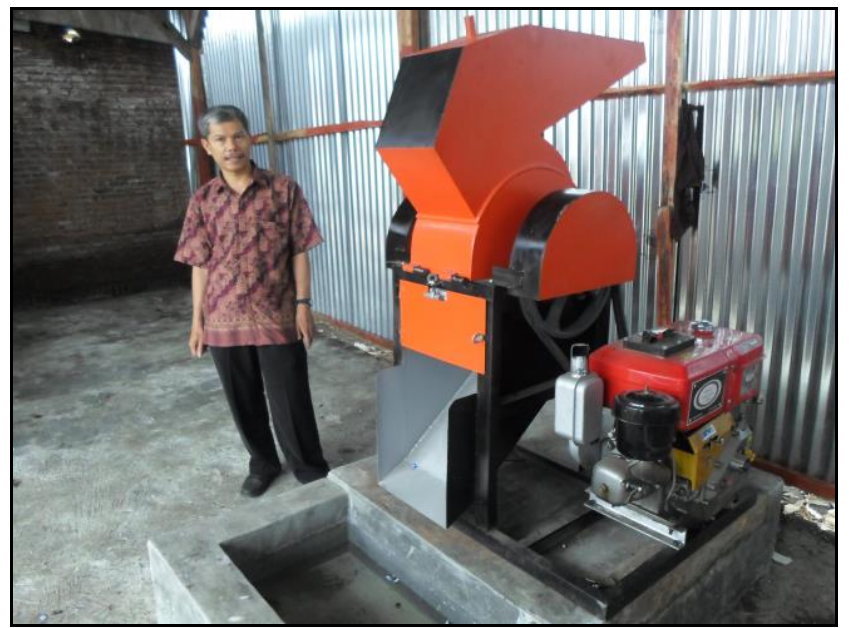

Gambar 3. Mesin pencacah sampah botol plastik

Kegiatan terakhir yaitu Monitoring dan evaluasi pada mitra IbM I dan mitra IbM II sebagai tindak lanjut keberlanjutan program yang dilaksanakan. Kegiatan ini dilakukan dengan dasar keberlanjutan agar progran ini terus berlanjut dan mengurangi sampah botol plastik untuk dijadikan biji plastik sehingga akan berdampak pada ekonomi kemasyarakatan. Monitoring dilakukan dengan durasi waktu setiap tri wulan, yaitu memonitor kinerja mesin dan juga memonitor manajemen produksi dari pencacahan limbah plastik yang ada pada mitra IbM II maupun pada mitra IbM II.

\section{KESIMPULAN}

Berdasarkan hasil dan pembahasan, dapat disimpulkan adalah sebagai berikut:

(1). Terciptanya prototipe dan mesin pencacah biji plastik, (2) transfer ilmu berupa teknologi mesin pencacah biji plastik dan penggunaannya, meningkatnya pemahaman kelompok pencacah biji plastik tentang teknologi dan paradikma daur ulang, (4) terciptanya bank sampah, sehingga dapat meningkatkan kesadaran kebersihan pada masyarakat, (5) hasil akhir dari kegiatan ini adalah biji plastik yang dapat bernilai ekonomis bagi masyarakat. (6) berkurangnya sampah botol plastik akibat pemanfaatnya menjadi biji plastik.

Berdasarkan kesimpulan yang diperoleh dalam pengabdian ini, maka dapat diajukan saran yang perlu menjadi pertimbangan bagi semua pihak yang berkepentingan adalah sebagai berikut: (1). proses pencacahan biji plastik seharusnya tidak hanya dilakukan satu kali, namun bisa 2 hingga 4 kali, (2). Tempat mesin pencacah biji plastik hendaknya ditempatkan di daerah yang jauh dari tempat tinggal masyarakat untuk menghindari pencemaran suara, atau dengan solusi yang lain dengan memberikan peedam suara dengan double tembok.

Dengan memanjatkan puji dan syukur penulis panjatkan kehadirat Allah SWT, karena dengan karunia dan petunjuk-Nya kepada penulis, akhirnya penulis dapat menyelesaikan pengabdian masyarakat program ipteks bagi masyarakat (IbM) ini sesuai rencana. Target khusus pada program ini nantinya dapat dijadikan wacana bagi masyarakat terhadap pengolahan sampah menjadi sesuatu yang bermanfaat, sehingga dapat menjadi terobosan dalam mengurangi jumlah sampah serta meningkatkan kesejahteraan kehidupan para kelompok usaha pencacah biji plastik.

Terima kasih yang tak terhingga penulis sampaikan kepada Direktorat Jendral Pendidikan Tinngi, Kementrian Pendidikan dan Kebudayaan Dana Dipa Kopertis VII Wilayah Jawa Timur Tahun Anggaran 2013 yang telah mermbantu dalam pendanaan pengabdian ini. Akhirnya, dengan segala kerendahan hati 
penulis mengharapkan kritik dan saran demi kesempurnaan laporan pengabdian masyarakat program ipteks bagi masyarakat (IbM) ini. Harapan saya, semoga karya yang sederhana ini dapat bermanfaat bagi semua pihak, penulis khususnya dan pembaca pada umumnya

\section{REFERENSI}

Alamedah, 2009. Dampak plastik terhadap lingkungan. http://alamendah. wordpress.com/2009/07/23/dampakplastik-terhadap-lingkungan/ (diakses 17 mei 2013).

Angelfire, 2012. Anti Sampah botol plastik.

http://www.angelfire.com/indie/ shefoughtbravely/sejarah.htm. (diakses 17 mei 2013).

Asgedom, Abraha Gebrekidan and Desta, Mulu Berhe. 2012. The Environmentalimpacts Of The Disposal Of Plastic Bags Andwater Bottles In Tigray, Northern Ethiopia. Sacha Journal of Environmental Studies, Volume 2 Number 1 (2012) pp. 81-94.

Macklin, Boy. 2008. Daur Ulang Sampah botol plastik Bisnis yang Menjanjikan dan Ramah Lingkungan. http://onlinebuku.com/2008/11/25/ daur-ulang-sampah-plastikmerupakan-bisnis-yang-menjanjikanserta-ramah-lingkungan/ (diakses 17 mei 2013).

Sentosa, Tozy. Plastik Bag Diet Campaig. http://www.centro.co.id/plastik-bagdiet/ (diakses 17 mei 2013).

Sulistyorini, Lilis. 2005. Pengelolaan Sampah Dengan Cara Menjadikannya Kompos. Jurnal Kesehatan Lingkungan, Vol. 2, No. 1, Juli 2005 : $77-84$.

SurabayaPostOnline. 2012. Pemkab Malang Kesulitan Olah Sampah botol plastik.

http://www.malangraya.info/2011/09/ 16/200435/4814/bank-sampah-kota- malang-diminati-pemerintah-osakajepang/(diakses 17 mei 2013).

Tempo, 2012. Sampah botol plastik. http://majalah.tempointeraktif.com (diakses 17 mei 2012). 